\title{
第43回（公社）日本口腔外科学会 中部支部学術集会講演題目
}

会 長: 渋谷恭之 (名古屋市立大学大学院医学研究科生体機能・構造医学専攻感覚器・形成医学講座口腔外科学分野教授)

日 時： 2018 年 6 月 23 日 (土) 会 場：桜山 (川澄) キャンパス (名古屋市立大学病院)

特別講演

国際的に活躍できる医師養成への挑戦

〜歯科医師養成への提言

国際医療福祉大学医学部 副医学部長・医学科長

吉田素文

ランチョンセミナー

エピシル ${ }^{\circledR}$ 口腔用液の使用経験

名古屋市立大学病院菌科口腔外科 菌科衛生士

山内千佳

\section{教育講演}

\section{Le Fort I 型骨切り術を安全に行うための基本術式}

新潟大学大学院医茵学総合研究科

組織再建口腔外科学分野 教授少林正治

下顎枝矢状分割術を安全に行うために

愛知学院大学菌学部罘口腔外科学特殊診療科 教授

吉田憲司

ビデオセッション

安全, 確実な上顎 Le Fort I 型骨切り術および

下顎枝矢状分割術を行うために

愛知学院大学靧口腔外科学講座 講師 横井 共

\section{一般演題}

1. 短期間で顎関節痛とともに開口障害と咬合不全を 生じた顎関節焱の 1 例

1) 愛知学院大学茵学部頑口腔外科学講座

2) 愛知学院大学茵学部柬科放射線学講座

$\bigcirc$ 中村有宏 ${ }^{1)}$, 小木信美 ${ }^{1)}$, 前多雅仁 ${ }^{1)}$, 片山良子 ${ }^{1)}$, 小熊哲史 ${ }^{1)}$, 野澤道仁 ${ }^{2)}$, 有地淑子 ${ }^{2)}$ ，有地榮一郎 ${ }^{2)}$ ，栗田賢一 ${ }^{1}$ )

2 . 咀嚼筋炎により生じた開口障害に対して ステロイド療法が奏効した 1 例

1) 中部労災病院菌科口腔外科

2) 豊田厚生病院菌科口腔外科

○水野 肇 ${ }^{1)}$, 宇佐見一公 ${ }^{2)}$, 鶴迫伸一 ${ }^{1)}$, 鈴木英治 ${ }^{1)}$

3 . 顎顔面領域に疼痛を呈した巨細胞性動脈炎の 臨床的検討

市立四日市病院歯科口腔外科

○水谷晃乃介, 石井 興, 藤井 仁, 前川裕貴, 小牧完二

4. 閉口障害を起こした $\lfloor 3$ 埋伏歯の 1 例

碧南市民病院菌科口腔外科

○釜本宗史，梅田敬史，山本圭一，小澤 悠, 藤浪 恒, 黒柳範雄

\section{5. 抗菌薬の適正使用を考慮した埋伏智歯抜歯術術後 感染予防の検討 \\ 岐皁県総合医療センター茵科口腔外科 \\ ○中島佑麻，木下路規，石丸京子，馬場政司， 石丸純一}


6. 感染源を特定できなかった頭䅡部ガス壊疽の 1 例

朝日大学付属村上記念病院菌科口腔外科

$\bigcirc$ 長縄鋼亮，榑沼 歩，山岡真太郎，高橋 萌， 篠島一将，松並晃弘，本橋征之，村松泰徳

7 . 治療に難渋した側頭部蜂窩織炎の 1 例

1) 愛知学院大学雬学部顎顔面外科学講座

2）岡崎市民病院菌科口腔外科

○上田佳緒璃 ${ }^{1)}$ ，落合栄樹 ${ }^{1)}$ ，宮地 斉 ${ }^{1)}$ 後藤満雄 ${ }^{1)}$, 渡邊 哲 ${ }^{1)}$, 宮部 悟 ${ }^{1)}$, 山本哲嗣 ${ }^{1)}$, 齊藤輝海 ${ }^{2}$, 長尾 徹 ${ }^{1}$ )

\section{8 . 食品用乾燥剤による口腔粘膜化学熱傷の 1 例}

国立病院機構名古屋医療センター霜科口腔外科

○松浦由佳，總山貴子，荒川美貴子，萩野浩子， 宇佐美雄司

\section{9. 呫癌再発を疑った黄色腫の 1 例}

1) 朝日大学口腔病態医療学講座口腔外科学分野

2）朝日大学口腔病態医療学講座口腔病理学分野

○金子裕康 ${ }^{1)}$ ，太田貴久 ${ }^{1 ｝ \text { ，長縄鋼亮 }{ }^{1)} \text {, }$ 住友伸一郎 ${ }^{1)}$, 中尾寿奈 ${ }^{2)}$, 江原道子 ${ }^{2)}$, 永山元彦 ${ }^{2)}$

\section{0. 舌に生じた神経鞘腫の 1 例}

1) 自衛隊富士病院菌科

2) 沼津市立病院菌科口腔外科

○松本鉄矢 ${ }^{1)}$, 谷口正光 ${ }^{1)}$, 今井須美子 ${ }^{2)}$, 井染 洋 ${ }^{2)}$, 岩重洋介 ${ }^{2)}$

\section{1. 舌対称性脂肪腫症の 1 例}

福井大学学術研究院医学系部門医学領域 感覚運動医学講座茵科口腔外科学分野

○吉田寿人，吉村仁志，領家 崇，大田圭一， 兒 梨恵, 松田慎平, 佐野和生

\section{2. 呫に発生した巨大な神経鞘腫の 1 例}

1) 厚生連高岡病院菌科口腔外科

2）金沢医科大学水見市民病院菌科口腔外科

○林 樹 ${ }^{1)}$, 松井俊明 ${ }^{2)}$, 山下知巳 ${ }^{1)}$
13. オトガイ部皮下に生じた棘融解性扁平上皮癌の 1 例 信州大学医学部柬科口腔外科学教室

○小田切宏樹，鎌田孝広，盛岡昌史，近藤英司， 山田慎一, 栗田 浩

\section{4. 服役中男性に生じた口底癌の治療経験}

1）富山赤十字病院雬科口腔外科

2) 富山大学大学院医学薬学研究部菌科口腔外科学講座

○石坂理紗 ${ }^{1,2)}$, 石戸克尚 ${ }^{2)}$, 冨原 圭 $^{2)}$,

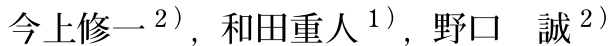

15. 下顎に発生した顎骨中心性紡鍾細胞癌の 1 例

1) 信州大学医学部茵科口腔外科学教室

2）慈泉会相澤病院口腔病センター

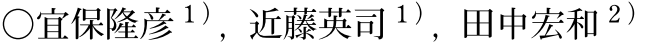
横関麻里 ${ }^{1)}$ ，鈴木大介 ${ }^{1)}$ ， 小田切宏樹 ${ }^{1)}$, 森下廣太 ${ }^{1)}$, 盛岡昌史 ${ }^{1)}$, 鎌田孝広 ${ }^{1)}$, 山田慎一 ${ }^{1)}$, 栗田 浩 ${ }^{1}$ )

16. PGA シートによる術創被覆による舌がん術後の 腫瘍切除面に炎症性肉芽腫性病変を認めた 1 例

1）石川県立中央病院菌科口腔外科

2）石川県立中央病院病理科

3) 明海大学茵学部病態診断治療学講座口腔顎顔面外科学

第 2 分野

○高木純一郎 ${ }^{1)}$ ，宮田 勝 ${ }^{1)}$ ，名倉 功 ${ }^{1)}$, 釜本崇史 ${ }^{1)}$, 車谷 宏 $^{2)}$, 坂下英明 ${ }^{3)}$

\section{7. 失神での転倒による下顎骨骨折の 1 例} 地域医療機能推進機構中京病院菌科口腔外科 ○牧 茉由子, 友松莉子, 森 建輔, 阿部友亮, 大島 綾，木下弘幸

18. 下顎骨骨折におけるハイブリッド MMF の使用経験

1）富山県立中央病院菌科口腔外科

2) 新潟大学大学院医茵学総合研究科 組織再建口腔外科学分野

○小島 拓 ${ }^{1)}$, 齋藤直朗 ${ }^{1,2}$ ， 中條智恵 ${ }^{1)}$ 
19. 顎関節脱臼の局麻手術後の重篤合併症 3 例

1）金沢医科大学顎口腔外科

2) ケイ茵科

○瀬上夏樹 ${ }^{1)}$, 加藤晃一郎 ${ }^{1)}$, 松本剛一 ${ }^{1)}$, 金山景錫 2$)$

20. 陳旧性両側顎関節脱臼に対し持続的牽引により

\section{非観血的整復した 1 例}

岐皁大学大学院医学系研究科口腔病態学分野

○杉山 健, 牧田浩樹, 阿部幸二郎，

畠山大二郎, 加藤恵三, 柴田敏之

21. ポリソムノグラフィーを用いた䋶変形症患者の 睡眠時咬筋活動の評価

金沢大学大学院医薬保健学総合研究科外科系

医学領域頸顔面口腔外科学分野

○麦谷圭昭, 大井一浩, 山下耀子, 井手健太郎, 大矢明日香，小林 泰，小林一彦，定梶 嶺， 北原寛子，野口夏代，加藤広禄，中村博幸， 川尻秀一

22. 下顎矢状分割術後に急性腹症を生じた 1 例 富山大学大学院医学薬学教育部菌科口腔外科学講座 ○石戸克尚, 富原 圭, 平識 亘, 櫻井航太郎, 今上修一，野口＼cjkstart誠

23. 骨病変内の歯の抜歯を行ったケルビズムの 1 例 三重大学大学院医学系研究科生命医科学専攻 臨床医学系講座口腔 · 靧顔面外科学分野 ○佐竹真実, 黒原一人, 新井直也

24. 長期間経過した線維性骨異形成症患者の減量術を 行った 1 例

朝日大学菌学部附属村上記念病院菌科・ 口腔外科

○篠島一将, 山岡真太郎, 長縄鋼亮, 榑沼 歩, 高橋 萌, 松並晃弘, 本橋征之, 村松泰徳
25. 名古屋市立大学病院における心臓血管外科患者の 周術期口腔機能管理の調査

1）名古屋市立大学病院菌科口腔外科

2) 名古屋市立大学大学院医学研究科

生体機能・構造医学専攻感覚器·形成医学講座 口腔外科学分野

○中野里奈 ${ }^{1)}$, 山内千佳 ${ }^{1)}$, 加古まり ${ }^{2)}$, 中西由佳理 ${ }^{2)}$, 高井美玲 ${ }^{2)}$, 須藤満理奈 ${ }^{2)}$, 宮本大模 ${ }^{2)}$, 渋谷恭之 ${ }^{2)}$

26. 当院での肺炎入院患者に対する口腔管理の

\section{取り組みについて}

春日井市民病院菌科口腔外科

○小林賢太朗，小原圭太郎，小島志乃， 近藤祐太朗，五藤義之，脇田 壮，丹下和久

27. 当院救命救急センターにおける歯科口腔外科疾患 の臨床統計学的検討

名古屋掖済会病院歯科口腔外科

○長谷川博亮，伊東 優，林 宏紀， 皆川将司，阿部 厚

28. 上気道管理に際しての医療用ピクトグラムの 有用性と今後の課題

碧南市民病院菌科口腔外科

○小澤 悠, 藤浪 恒, 黒柳範雄

29. 局所麻酔により顔面浮腫をきたした遺伝性血管性 浮腫の 1 例

愛知医科大学大学院医学研究科口腔外科学

○西尾佳朋, 山本康博, 伊藤邦弘, 林 富雄, 古橋明文，大野隆之，風岡宜暁

30. 口唇腺に唾石を認めた 1 例

名古屋市立西部医療センター茵科口腔外科

○片岡達哉, 渡邊裕之, 加藤伸一郎, 奥村嘉英, 島一幹, 深野英夫 
31. IgG4 関連顎下腺炎を疑った 1 例

公立陶生病院菌科口腔外科

○吉崎亮介，神谷祐二，服部雄紀，

中山英典，小川裕之

32. 歯科用金属アレルギーのパッチテストを実施した 患者の臨床的検討

豊田厚生病院菌科口腔外科

○望月大督，兼子隆次，宇佐見一公，河合孝真

33. 口唇に生じた放線菌症の 3 例

岡崎市民病院歯科口腔外科

○柏原 捷，大隅縁里子，大林修文，伊藤洋平， 前田千芽, 斉藤輝海

34. 呫膿瘍の 2 例

一宮市立市民病院菌科口腔外科

○豊田貴久, 佐藤文彦, 竹内 豪, 紀藤一将, 山田雄已, 中村友保

\section{5. 口角潰瘍を初発症状とした梅毒の 1 例}

1）国立病院機構名古屋医療センター菌科口腔外科

2) 名古屋大学大学院医学系研究科

頭頸部 ·感觉器外科学講座

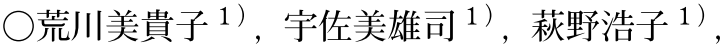
總山貴子 ${ }^{1)}$ ，松浦由佳 ${ }^{1}$ ，日比英晴 ${ }^{2)}$

36. 口腔内多発血腫を契機に明らかとなった 後天性血友病 $\mathrm{A}$ の 1 例

1）松阪市民病院菌科口腔外科

2) 奈良県立医科大学口腔外科学講座

○有川 翔 ${ }^{1)}$, 松山博道 ${ }^{1)}$, 中橋一裕 ${ }^{1)}$, 桐田忠昭 ${ }^{2)}$

37. 両側に第二大臼歯の歯根吸収を伴った下顎智歯の 濾胞性歯襄胞を認めた 1 例

公立松任石川中央病院歯科口腔外科

○岡部克彦, 高塚茂行
38. 広範な歯槽骨吸収を伴った鼻口蓋管囊胞の 1 例 浜松医科大学医学部附属病院茵科口腔外科

○堀野裕太，渡邊賀子，小笠原佑樹，小川主税 加藤雄大, 増本一真, 加藤文度

39. 顎骨囊胞への感染を契機に判明した 鎖骨頭蓋異骨症の 1 例

浜松医科大学医学部附属病院歯科口腔外科

○坪井佑奈，渡邊賀子，小川主税，小笠原佑樹， 加藤雄大, 増本一真, 加藤文度

40. 根尖から下顎下縁に至り舌側皮質骨を穿破した 歯根囊胞に対して decompression tube を用いた 開空療法により手術侵襲を軽減した 1 例 岐皁県立多治見病院菌科口腔外科

○丹羽裕明，河原 康，高瀬建成，折山資， 大平芽実，小栗 崇，柴田章夫

41. 未手術粘膜下口蓋裂症例の臨床的研究 一第 7 報 未手術患者 15 例の長期経過について一 1) 愛知学院大学茵学部附属病院言語治療外来部門

2）愛知学院大学茵学部附属病院口唇口蓋裂センター ○森 智子 1,2)，新美照幸 1,2 ）, 井上知佐子 1,2 ）, 早川統子 1), 相原喜子 ${ }^{1,2)}$, 大久保瑞姫 ${ }^{2)}$, 井村英人 1,2 ), 吉田磨弥 ${ }^{1,2)}$, 佐久間千里 ${ }^{1,2}$ ), 南 克浩 ${ }^{1,2}$ ), 齋藤直樹 ${ }^{2)}$, 古川博雄 ${ }^{1,2}$, , 夏目長門 1,2$)$

42. 両側性唇顎口蓋裂患者における 8 回目の 全身麻酔手術で悪性高熱症を認めた 1 例 愛知学院大学茵学顎口腔外科学講座 $\bigcirc$ 今岡功喜, 中山敦史, 花井寞之, 松井義人, 水野頌也, 前多雅仁, 向井加奈, 栗田賢一

\section{3. 直線法口唇形成術の初期経験}

富山大学大学院医学薬学研究部菌科口腔外科講座 $\bigcirc$ 野口 誠, 藤原久美子，今上修一，冨原 圭 
44. 出生時に上下顎歯槽頂に乳歯様構造物を認めた 新生児の 1 例

1) 名古屋第一赤十字病院茵科

2) 九州大学大学院茵学研究院口腔顎顔面病態学講座 顎顔面腫瘍制御学分野

3 ) 名古屋第一赤十字病院口腔外科

○丸瀬靖之 ${ }^{1,2)}$, 長縄憲亮 ${ }^{3)}$, 佐藤春樹 ${ }^{3)}$, 早川泰平 ${ }^{3)}$, 小野翔矢 ${ }^{1)}$, 大原令子 ${ }^{1)}$, 佐久間英規 ${ }^{1)}$, 大岩伊知郎 1,3$)$

45. 右頓粘膜下に発生した孤立性線維性腫瘍の 1 例 豊川市民病院歯科口腔外科

○森下佳学, 鈴木慎太郎, 長谷川正午, 神道紀衣, 畔柳 豪

46. 上顎洞に及んだ上顎歯原性粘液腫の 1 例 信州大学医学部㐘科口腔外科学教室 ○横関麻里，鎌田孝広，西牧史洋，盛岡昌史， 近藤英司，山田慎一，栗田 浩

47. 当科における口腔白板症・紅板症症例の細胞診 および組織診の臨床病理学的検討

松本菌科大学茵学部口腔罘顔面外科学講座

○芳澤享子, 高田寛子, 松村奈穂美, 内川恵里, 齋藤安奈, 森こず恵, 丸川和也, 中山洋子, 各務秀明

48. 当科におけるロ腔扁平苔癬の臨床および 病理組織学的検討

松本㐘科大学茵学部口腔顎顔面外科学講座

○内川恵里，高田寛子，松村奈穂美，齋藤安奈， 森こず恵, 丸川和也, 中山洋子, 各務秀明, 芳澤享子
49. 腫瘤状カンジダ性正中菱形舌炎の 1 例

1）富山赤十字病院茵科口腔外科

2) 富山大学病院茵科口腔外科

$\bigcirc$ 和田重人 1)，丹羽佳世子 1,2 ）, 石坂理紗 1,2 ）, 平識 亘 ${ }^{1,2}$ )

50. 下顎埋伏智歯歯胚感染に起因したと考えられた Garré 骨髄炎の 1 例

1) 藤田保健衛生大学病院柬科 - 口腔外科

2) 藤田保健衛生大学医学部柬科 - 口腔外科

○内匠 悟 ${ }^{1)}$, 小林義和 ${ }^{2)}$, 近石壮登 ${ }^{2)}$, 竹原庸介 ${ }^{2)}$, 奥井太郎 ${ }^{2)}$, 相澤貴子 ${ }^{2)}$, 佐藤公治 ${ }^{2)}$, 松尾浩一郎 2 )

歯科臨床医リフレッシュセミナー

サージカルトレーニングの意義と顎顔面領域の

解剖について

名古屋市立大学大学院医学研究科

統合解剖学分野 教授

植木孝俊 